\title{
Antigen production and development of an indirect ELISA based on the nucleocapsid protein to detect human SARS-CoV-2 seroconversion
}

\author{
Marcelo S. Conzentino ${ }^{1} \cdot$ Karl Forchhammer $^{2} \cdot$ Emanuel M. Souza $^{3} \cdot$ Fábio O. Pedrosa $^{3} \cdot$ Meri B. Nogueira $^{4}$. \\ Sônia M. Raboni ${ }^{4}$. Fabiane G. M. Rego ${ }^{5}$. Dalila L. Zanette ${ }^{6} \cdot$ Mateus N. Aoki $^{6}$. Jeanine M. Nardin ${ }^{7}$. Bruna Fornazari ${ }^{7}$. \\ Hugo M. P. Morales ${ }^{7}$. Paola A. F. Celedon ${ }^{8}$. Carla V. P. Lima ${ }^{8}$. Sibelle B. Mattar ${ }^{8}$. Vanessa H. Lin ${ }^{8} \cdot$ Luis G. Morello $^{6,8}$. \\ Fabricio K. Marchini ${ }^{6,8} \cdot$ Rodrigo A. Reis $^{1} \cdot$ Luciano F. Huergo $^{1}$
}

Received: 15 March 2021 / Accepted: 21 June 2021 / Published online: 3 August 2021

(c) Sociedade Brasileira de Microbiologia 2021

\begin{abstract}
Serological assays are important tools to identify previous exposure to SARS-CoV-2, helping to track COVID-19 cases and determine the level of humoral response to SARS-CoV-2 infections and/or immunization to future vaccines. Here, the SARS-CoV-2 nucleocapsid protein was expressed in Escherichia coli and purified to homogeneity and high yield using a single chromatography step. The purified SARS-CoV-2 nucleocapsid protein was used to develop an indirect enzyme-linked immunosorbent assay for the identification of human SARS-CoV-2 seroconverts. The assay sensitivity and specificity were determined analyzing sera from 140 RT-qPCR-confirmed COVID-19 cases and 210 pre-pandemic controls. The assay operated with $90 \%$ sensitivity and $98 \%$ specificity; identical accuracies were obtained in head-to-head comparison with a commercial ELISA kit. Antigen-coated plates were stable for up to 3 months at $4{ }^{\circ} \mathrm{C}$. The ELISA method described is ready for mass production and will be an additional tool to track COVID-19 cases.
\end{abstract}

Keywords SARS-CoV-2 $\cdot$ COVID-19 $\cdot$ Immunological test $\cdot$ ELISA $\cdot$ Nucleocapsid protein

\section{Introduction}

Responsible Editor: Fernando R. Spilki

Luciano F. Huergo

luciano.huergo@gmail.com

1 Setor Litoral, UFPR, Matinhos, Paraná, Brazil

2 Interfakultäres Institut Für Mikrobiologie Und Infektionsmedizin der Eberhard-Karls Universität Tübingen, Tübingen, Germany

3 Biochemistry and Molecular Biology Department, UFPR, Curitiba, Paraná, Brazil

4 Complexo Hospital das Clínicas, UFPR, Curitiba, Paraná, Brazil

5 Post-Graduation Program in Pharmaceutical Sciences, UFPR, Curitiba, Paraná, Brazil

6 Instituto Carlos Chagas - FioCruz, Curitiba, Paraná, Brazil

7 Hospital Erasto Gaertner, Curitiba, Paraná, Brazil

8 Instituto de Biologia Molecular Do Paraná, IBMP, Curitiba, Paraná, Brazil
In December 2019, health authorities in Wuhan, China, reported cases of patients with pneumonia of unknown epidemiological causes, linked to a seafood/animal market. The pathogen in these cases has been identified, through viral isolation, electron microscopy, and RNA sequencing, as a new beta-coronavirus called SARS-CoV-2 [1]. Shortly after its emergence in China, SARS-CoV-2 spread rapidly across the world. According to the John Hopkins University website (https://coronavirus.jhu.edu/map.html), on 01/02/2021, more than 100 million cases of COVID-19 have been registered worldwide and the disease was responsible for 2,236,000 deaths.

Serological assays are important for epidemiological surveillance studies to monitor COVID-19 cases [2]. The structural nucleocapsid $(\mathrm{N})$ protein is known to be a major antigen of coronavirus producing a strong humoral response in humans [3]. Furthermore, the SARS-CoV-2 nucleocapsid protein can be used as antigen to detect COVID-19 cases without significant cross-reactivity with common cold 
coronavirus [4]. Here, we describe and develop an indirect enzyme-linked immunosorbent assay (ELISA) which allowed accurate detection human anti-IgG SARS-CoV-2 seroconversion.

\section{Results and discussion}

A codon optimized synthetic gene was obtained and cloned into the pET28a vector to allow the expression of an N-terminal 6xHis tagged SARS-CoV-2 N-protein in Escherichia coli BL21 ( $\lambda \mathrm{DE} 3)[5,6]$. The viral protein was highly expressed and remained partially soluble in $E$. coli cell extracts (Fig. 1A). The protein was purified using a $5-\mathrm{ml}$ His-trap affinity column (Cytiva) followed by elution with an imidazole gradient. The His-tagged SARS-CoV-2 N-protein eluted at $300 \mathrm{mM}$ of imidazole to apparent homogeneity on Coomassie-stained SDS-PAGE (Fig. 1A). Typical protein yield was $\sim 8 \mathrm{mg}$ per $100 \mathrm{ml}$ of culture; the antigen was stored for up to 4 months at $-20{ }^{\circ} \mathrm{C}$.

The purified N-protein was diluted in buffer and used to coat 96-well polystyrene plates overnight at $4{ }^{\circ} \mathrm{C}$.
Plates were blocked with skimmed milk and serum from a COVID-19 positive case and a negative control serum were serially diluted and placed into the wells of pre-coated plates. The presence of $\mathrm{IgG}$ reacting with the SARS-CoV-2 N-protein was revealed by incubating with secondary anti-human IgG-HPR followed by chromogenic substrate TMB. The COVID-19 positive serum showed strong reaction with the N-protein even at high dilutions (Fig. 1B). On the other hand, the negative control serum showed only minor background cross-reaction in low dilutions (Fig. 2A). The OD450nm response vs serum dilution of the positive serum was linear between the 1600 and the 25,600 dilutions with $\mathrm{R}^{2}=0.995$ (Fig. 1C). This positive serum was used as a positive control throughout this study; the inter assay CV\% was $7.2 \%$ (same sample run in 12 different plates in duplicate). The mean intra assay CV\% was $7.6 \%$ (mean CV\% was obtained from duplicate 96 samples $\times 12$ plates).

To validate our ELISA assay to detect SARS-CoV-2 seroconversion in a human cohort consisting of 140 RT-qPCRconfirmed COVID-19 cases and 210 pre-pandemic negative controls were used. The pre-pandemic control sera produced
Fig. 1 Purification of the SARSCoV-2 nucleocapsid protein and serum dilution analysis on ELISA. A SDS-PAGE analysis of purified His-tagged SARSCoV-2 N-protein. Lane 1, whole cell extract; lane 2, soluble fraction; lane 3 , insoluble fraction; lane 4, column flow through; other lanes, imidazole gradient; the N-protein is indicated by an arrow and eluted at $300 \mathrm{mM}$ imidazole. B The sera from a COVID-19-positive case and from a negative control were serially diluted and analyzed using indirect ELISA; the data were recorded photographically. $\mathbf{C}$ The data derived from the COVID-19-positive case was expressed as OD values vs reciprocal dilution; the dashed line indicates the dilution used during this study
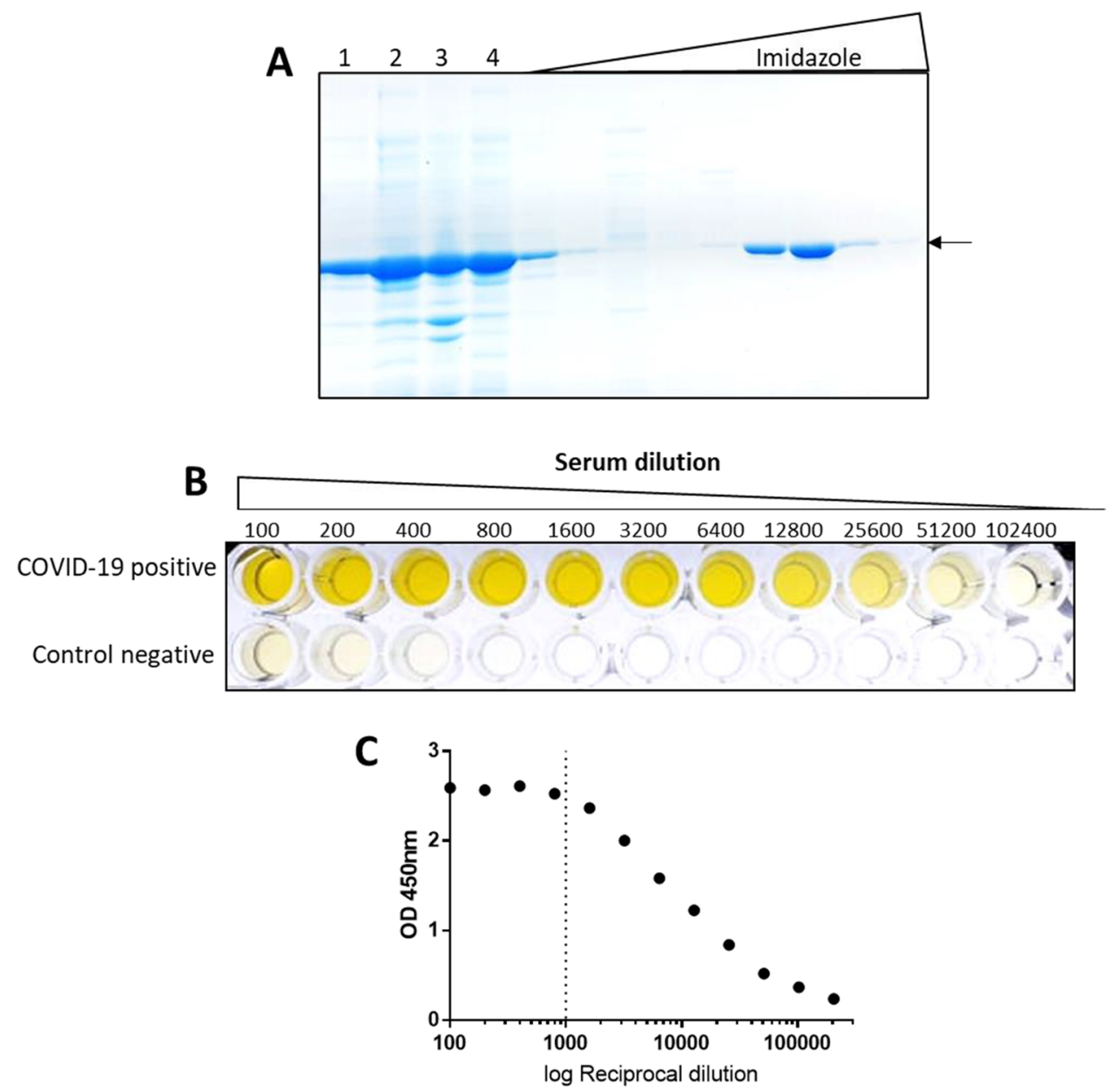

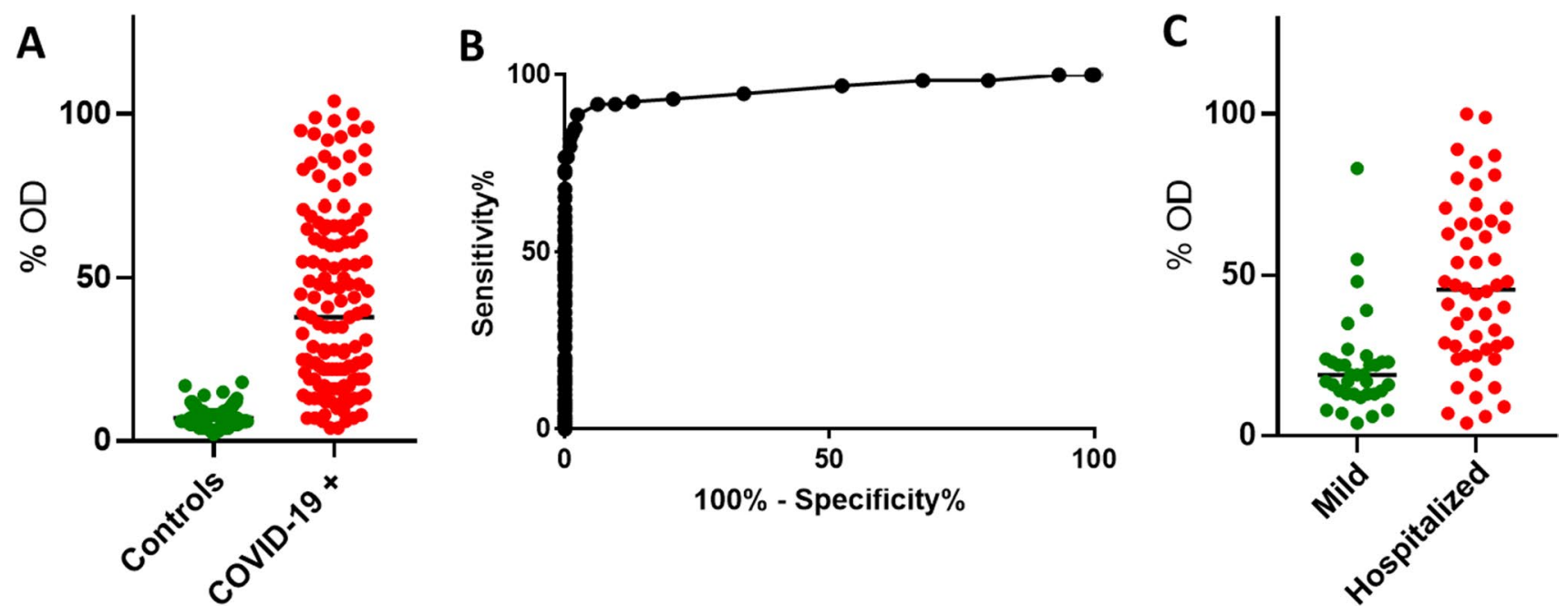

Fig. 2 IgG seroconversion response to SARS-CoV-2 infection. A The OD was expressed as the percent of reference serum for negative control samples $(n=210)$ and PCR-confirmed COVID-19 cases $(n=140)$. B Receiver operating characteristics (ROC) analysis of the

only background signal which were clearly distinguished from the RT-qPCR-confirmed COVID-19 cases (Fig. 2A). The age of the negative cohort ranged from 21 to 86 years of age $($ mean $=62)$. It is likely that most of these subjects had experienced prior infections with common coronavirus (229E, NL63, OC43, and HKU which usually cause mild upper-respiratory tract disease, like the common cold). These data suggest that our ELISA assay shows negligible cross-reactivity for $\mathrm{IgG}$ raised against common coronavirus. However, it is worth mentioning that we detected 4 reactive pre-pandemic samples whose signals were above the established cutoff thereby being classified as false positives (Fig. 2A). Such reactivity could be potentially explained by cross-reaction with $\mathrm{IgG}$ raised against common coronavirus.

The ELISA method operated with an area under the ROC curve of 0.96 (Fig. 2B); the cutoff the assay was set at $90 \%$ sensitivity (83.8-94.4\% at $95 \% \mathrm{CI}$ ) and $98 \%$ specificity $(95.2-99.5 \%$ at $95 \% \mathrm{CI})$. These values are in the same range for other SARS-CoV-2 immunological IgG tests described previously $[4,7,8]$. It is worth mentioning that among the RT-qPCR-confirmed COVID-19 cases, 32 samples were in the early stage of infection ( $\leq 10$ days after detection), and this may explain the low sensitivity. Indeed, if only samples collected $\leq 10$ days after detection were considered, the sensitivity dropped to $81 \%$. It is also worth mentioning that 40 samples of the COVID-19-positive cohort were from asymptomatic/mild COVID-19 cases which are known to induce lower humoral response to SARS-CoV-2 infections [9]. Indeed, our analysis confirmed that the IgG titer was significantly lower in mild versus hospitalized COVID-19 patients (Fig. 2C). data described in A. C Comparison between the $\mathrm{IgG}$ signal reacting with the SARS-CoV-2 nucleocapsid protein in mild and hospitalized RT-qPCR-confirmed COVID-19 cases. Groups were compared using the T test

A panel of 90 samples was analyzed in parallel by our developed ELISA and the Euroimmun nucleocapsid-based IgG ELISA. All the 44 pre-pandemic negative samples analyzed were negative in both tests confirming the high specificity of the assays. Out of the 46 RT-qPCR-confirmed COVID-19 samples, both tests missed 4 samples (false negatives). One sample was negative in both tests, and three samples were uniquely negative in each of the two different tests. These data support that our ELISA performed with similar sensitivity to the commercial Euroimmun ELISA test.

In conclusion, here, we describe a high yield and simple method to purify the SARS-CoV-2 nucleocapsid antigen using only one simple affinity chromatography step. The antigen preparation was used to develop an indirect ELISA which allowed accurate detection of SARS-CoV-2 seroconversion in humans. The developed assay is ready for mass production in order to help to track COVID-19 cases especially in developing countries where access to molecular test is limited.

\section{Material and methods}

\section{Expression and purification of recombinant SARS-CoV-2 nucleocapsid protein (N-protein)}

A codon optimized synthetic gene expressing the fulllength SARS-CoV-2 N-protein (Uniprot QHD43423.2) was obtained and cloned into pET28a by General Biosystems [6]. This plasmid was named pLHSarsCoV2-N and transformed into $E$. coli BL21 ( $\lambda \mathrm{DE} 3$ ) enabling the 
expression of $\mathrm{N}$-terminal His-tagged $\mathrm{N}$-protein after induction with IPTG. The cells were grown in $100 \mathrm{ml}$ $\mathrm{LB}$ medium at $120 \mathrm{rpm}$ at $37^{\circ} \mathrm{C}$ to $\mathrm{OD}_{600 \mathrm{~nm}}$ of 0.4 . The incubator temperature was lowered to $16^{\circ} \mathrm{C}$, after $30 \mathrm{~min}$, IPTG was added to a final concentration $0.3 \mathrm{mM}$ and the culture was kept at $120 \mathrm{rpm}$ at $16{ }^{\circ} \mathrm{C}$ overnight. Cells were collected by centrifugation at $3000 \times \mathrm{g}$ for $5 \mathrm{~min}$. The cell pellet was resuspended in $20 \mathrm{ml}$ of buffer 1 (Tris- $\mathrm{HCl}$ pH 8, $50 \mathrm{mM}, \mathrm{KCl} 100 \mathrm{mM}$, glycerol 10\%). Cells were disrupted by sonication on an ice bath. The soluble fraction was recovered after centrifugation at $20,000 \times \mathrm{g}$ for $20 \mathrm{~min}$ and loaded onto a $5 \mathrm{ml}$ His-Trap column (Cytiva), which had been previously equilibrated with buffer 1 . The column was washed with $10 \mathrm{ml}$ of buffer 1 , and bound proteins were eluted with buffer 1 containing increasing concentrations of imidazole. The His-tagged $\mathrm{N}$-protein was eluted at $300 \mathrm{mM}$ imidazole. The final protein preparation yield was $\sim 8 \mathrm{mg}$ and was homogeneous as judged by SDSPAGE analysis. The purified protein was stored in aliquots at $4{ }^{\circ} \mathrm{C}$ for 1 week or at $-20^{\circ} \mathrm{C}$ for up to 4 months.

\section{Human samples}

Samples were collected at the Hospital de Clínicas (CHC/ UFPR), Hospital Erasto Gaertner, Hospital do Trabalhador, and Secretária Municipal de Saúde de Guaratuba. Samples for serological analysis comprised both serum and plasma-EDTA. COVID-19-positive cases were confirmed by the detection of SARS-CoV-2 RNA by RT-qPCR from nasopharyngeal sample swabs. The time point of sampling of serum ranged from 1 to 70 days after onset of symptoms. The cohort of 210 negative controls consisted of pre-pandemic samples. The Institutional Ethics Review Board of CHC/UFPR (n\# 30,578,620.7.0000.0008), CEP/HEG (n\# 31,592,620.4.1001.0098), CEP/HT (n\# 31,650,020.5.0000.5225) and CEP/UFPR ( $n \#$ 43946621.7.0000.0102) approved this study.

\section{ELISA assays}

The purified SARS-CoV-2 N-protein was diluted to $2 \mathrm{ng} / \mu \mathrm{l}$ in $50 \mathrm{mM}$ Tris- $\mathrm{HCl} \mathrm{pH} \mathrm{8,100} \mathrm{mM} \mathrm{KCl,} \mathrm{10 \%} \mathrm{(v/v)} \mathrm{glycerol,}$ and $0.1 \mathrm{ml}$ aliquots were transferred to the wells of ELISA plates (Olen) and incubated overnight at $4{ }^{\circ} \mathrm{C}$. Unbound excess protein was removed, and wells were washed twice with $0.2 \mathrm{ml}$ of $1 \times$ TBST buffer $\mathrm{pH} 7.6$ (Tris $2.42 \mathrm{~g} . \mathrm{l}^{-1}, \mathrm{NaCl}$ $8 \mathrm{~g} . \mathrm{l}^{-1}$, and Tween $\left.800.1 \% \mathrm{v} / \mathrm{v}\right)$. Wells were blocked with $0.2 \mathrm{ml} \mathrm{3 \%}(\mathrm{w} / \mathrm{v})$ skimmed milk in $1 \times$ TBST overnight at $4{ }^{\circ} \mathrm{C}$. The serum was diluted at 1:1000 in $1 \times$ TBST containing $1 \%(\mathrm{w} / \mathrm{v})$ skimmed milk, and $0.1 \mathrm{ml}$ was loaded onto the ELISA duplicate wells following by incubation at room temperature for $1 \mathrm{~h}$. The wells were washed three times with $0.2 \mathrm{ml}$ of $1 \times$ TBST followed by incubation with $0.1 \mathrm{ml}$ of anti-human IgG-HPR from goat (Thermo Fisher-cat number $62-8420$ ) diluted 1:3000 in $1 \times$ TBST. Wells were washed three times with $0.2 \mathrm{ml}$ of $1 \times$ TBST. The HPR substrate TMB (Thermo Fisher-cat number 00-2023) was added to the wells $(0.1 \mathrm{ml})$. The reaction was stopped after a 10-min incubation at room temperature by addition of $0.1 \mathrm{ml}$ $1 \mathrm{M} \mathrm{HCl}$. The plates were put on the top of a white light transilluminator device and photographed. Samples were run in duplicates and data were reported as the percent of a positive reference serum. The optical density was measured at $450 \mathrm{~nm}$ using a TECAN M Nano plate reader (TECAN) monochromator at bandwidth $9 \mathrm{~nm}$ and 25 flashes.

The commercial Euroimmun Anti-SARS-CoV-2 ELISA $\mathrm{IgG}$ test was used following the manufacturer's instructions.

\section{Data analysis}

One COVID-19-positive serum was used as a positive control and reference throughout the study. All data were expressed as the percent of this positive control before applying receiver operating analysis using GraphPad Prism 7.0. Statistical analyses were performed using the $t$ test.

Funding This work was supported by the Alexander von Humboldt foundation and The Federal University of Paraná, Brazil. MC received an undergraduate technological development fellowship from $\mathrm{CNPq}$ (PIBIT-UFPR).

\section{Declarations}

Conflict of interest The authors declare no competing interests.

\section{References}

1. Zhu N, Zhang D, Wang W et al (2020) A novel coronavirus from patients with pneumonia in China, 2019. N Engl J Med. https:// doi.org/10.1056/NEJMoa2001017

2. Petherick A (2020) Developing antibody tests for SARS-CoV-2. Lancet. https://doi.org/10.1016/s0140-6736(20)30788-1

3. Cheng VCC, Lau SKP, Woo PCY, Kwok YY (2007) Severe acute respiratory syndrome coronavirus as an agent of emerging and reemerging infection. Clin Microbiol Rev. https://doi.org/10.1128/ CMR.00023-07

4. den Hartog G, Schepp RM, Kuijer M et al (2020) SARS-CoV-2specific antibody detection for seroepidemiology: a multiplex analysis approach accounting for accurate seroprevalence. J Infect Dis. https://doi.org/10.1093/infdis/jiaa479

5. Huergo LF, Conzentino MS, Gerhardt ECM et al (2020) Magnetic bead-based ELISA allow inexpensive, rapid and quantitative detection of human antibodies against SARS-CoV-2. medRxiv. https://doi.org/10.1101/2020.07.26.20162255

6. Huergo LF, Selim KA, Conzentino MS et al (2021) Magnetic bead-based immunoassay allows rapid, inexpensive, and quantitative detection of human SARS-CoV-2 antibodies. ACS Sensors 0(0). https://doi.org/10.1021/acssensors.0c02544 
7. Cai X, Chen J, Li Hu J et al (2020) A peptide-based magnetic chemiluminescence enzyme immunoassay for serological diagnosis of coronavirus disease 2019. J Infect Dis. https://doi.org/ 10.1093/infdis/jiaa243

8. Rikhtegaran Tehrani Z, Saadat S, Saleh E et al (2020) Specificity and performance of nucleocapsid and spike-based SARS-CoV-2 serologic assays. medRxiv. https://doi.org/10.1101/2020.08.05. 20168476

9. Long QX, Tang XJ, Shi QL et al (2020) Clinical and immunological assessment of asymptomatic SARS-CoV-2 infections. Nat Med. https://doi.org/10.1038/s41591-020-0965-6
Publisher's note Springer Nature remains neutral with regard to jurisdictional claims in published maps and institutional affiliations. 